T OVE T Y B J ER G

\title{
Wilhelm Mannhardt - A Pioneer in the Study of Rituals
}

In the history of the study of religion the German folklorist Wilhelm Mannhardt (1831-1880) was the first to undertake a systematic study of rituals.

This was not because of a specific interest in rituals; Mannhardt's interests lay with mythology, and all his life he regarded himself as a mythologist. In focusing on mythology Mannhardt was in tune with the spirit of his age, but to undertake a systematic study of rituals was something new. At the time the novelty of this approach went practically unnoticed, and Mannhardt himself barely reflected on method. I have chosen to focus on Mannhardt's creative approach to the study of ritual, partly because it is somewhat overlooked, partly because it illuminates in a nearly exemplary way some of the basic strengths of a ritual centred approach to the study of religion.

\section{Mannhardt's Background}

Mannhardt's love for mythology came to him at an early age. During his childhood a crippling back disease tied him to his bed for long periods of time. One summer he read Jacob Grimm's Deutsche Mythologie:

Es waren die Sommerferien; der Augustapfelbaum inmitten unseres Gartens warf mir seine rotbackigen Früchte in den Schoss. So habe ich, damals Secundaner, das schwererrungene Meisterwerk von Anfang bis Ende gelesen und die Richtung meines Lebens war entschieden. (Mannhardt 1874-76/2: viii) 
In Deutsche Mythologie Grimm sought to recreate an old German mythology from the scanty existent sources. Among these he included folklore, assuming that he would find there the worn-out remnants of an old German pantheon. Mannhardt initially followed similar lines of thought, but he soon became aware of the weaknesses of some of Grimm's basic assumptions. Following the mythologist Wilhelm Schwartz, it became clear to Mannhardt that, generally speaking, folklore could not be taken as remnants, but had to be regarded as an old and very stable layer of "lower mythology", the seeds or the essential elements wherefrom "higher mythology" developed. Folkloristic material was to be regarded as survivals - "Überlebsel" - as Mannhardt says with direct reference to the English anthropologist Edward Tylor (Mannhardt 1874-76/2: xxii--xxiii).

Apart from being occupied with questions of origin, 19th century historians of religion characteristically drew on comparative studies in IndoEuropean languages and myths and tended to be rather romantic in their interpretations; Indo-European gods were seen as personifications of heavenly phenomena like the dawn, the tempest, and thunder and lightning. Mannhardt worked with similar interpretations in his first publications Germanische Mythen (1858) and Götterwelt der deutschen und nordischen Völker (1860). Unlike many of his contemporaries, however, he did take heed of the critique from more sober-minded philologists; so much so, in fact, that after a physical and psychological crisis he decided upon a complete change of approach. Should Grimm's work be continued, the foundation had to be different:

Bleibenden Gewinn versprach nur eine solche Fortführung des begonnenen Riesenwerkes, welche zunächst einmal in dem Baumaterial selber sich orientierte und ohne Rücksicht auf ein vorher bestimmtes Resultat die Volksüberlieferungen einerseits unter sich, andererseits mit den zunächstliegenden verwandten Erscheinungen verglich. (Mannhardt 1874-76/2: xiv)

To remedy the deficiencies in existing collections of folklore, and to establish a sound foundation for further studies, Mannhardt decided to start his own collection. All-inclusive collection would be impossible, and Mannhardt limited himself to a survey of customs related to farming, especially harvest customs. From the beginning of the 1860's to his death Mannhardt was engaged in collecting material via widely distributed questionnaires. Mannhardt never published his material as was his intention, mainly because he was never satisfied with it; he used it in parts in what was to become his main published work, Wald- und Feldkulte (1874-1876). 


\section{Wald- und Feldkulte - Mannhardt as Mythologist}

In Wald-und Feldkulte Mannhardt works his way through the material on cults of the fields and woods in Northern Europe and in antiquity. Behind all these customs and myths Mannhardt finds one single idea. This "Grundanschauung" is the conception of "die Vegetationsdämon", the vegetation-daemon. The daemon is the personification of plants or plant life. In the first volume Der Baumkultus der Germanen und ihrer Nachbarstämme: mythologische Untersuchungen (1874-76/1), Mannhardt examines the vegetation-daemon in European folklore; he begins with simple forms like trees of life or destiny and forest people like elves and fairies; he continues with the rich variety of customs connected with spring and harvest festivals, like the May Trees in spring and "die Erntemai" at harvest together with various customs conñected with "the last sheaf". In volume two, Antike Wald-und Feldkulte aus nordeuropäischer Überlieferung erläutert (1874-76/2), and in the posthumously published Mythologische Forschungen (1884), Mannhardt traces these concepts back in time and finds similar customs in antiquity. The parallels are striking, but the historical connections are difficult to trace, and Mannhardt finds it impossible to know whether the parallels are due to common origin, to later loans or diffusions, or to the fact that similar customs might originate in similar conditions. Mannhardt points to the parallels and thereby the possibility to understand the scanty sources from antiquity in analogy with contemporary folk traditions.

Because of the mythological bias in Mannhardt's thinking he tended to generalize in terms of a proto-mythical figure. Behind the vegetationdaemon is a theory of animation and personification, primarily based on the different names given to trees, boughs, sheaves, dolls or leafcovered persons. Mannhardt's emphasis is on the names and he pays lesser attention to the ritual forms. Mannhardt has, in fact, been mythicizing the connections between vegetation and human beings in a much more real sense than the folk traditions did. Despite this mythicizing tendency, the conception of the vegetation-daemon represents a new understanding of the religious meaning of nature. Although Mannhardt was thinking in terms of myth, he was working with traditions deeply rooted in everyday practical life, and he realized that the attitude towards nature in these traditions was of a practical-technical character, not poetic-romantic as the nature-mythologists perceived it. Mannhardt's realization was won through his effort to gather reliable folkloristic source material, that is through his survey. 


\section{Mannhardt's Survey}

Mannhardt made his survey alone and at his own expense. He sent out 150,000 questionnaires and received 2,000 answers. He sent his questionnaire all over Germany to priests, teachers, farmers' associations, training colleges; he sent it to neighbouring countries; he had it translated into several languages and sent out in France and the Scandinavian countries. Whenever he found knowing people, they were used as informants. When prisoners of war came to camps near Danzig from Denmark in 1864, Mannhardt interviewed the soldiers about the harvest customs of their homelands, and when they came from Elsass-Lothringen in 1870-1871, he likewise made an effort to give them his questionnaire.

In spite of Mannhardt's untiring efforts, he did not succeed in establishing a collection of material with complete geographical coverage; that was his goal and his failure in achieving it was his main reason for postponing publication. As early as 1860 , in the foreword to Göterwelt, Mannhardt had already laid out plans for a systematic collection of folk traditions and in the foreword to the first publication based on his own material, Roggenwolf und Roggenhund from 1865 , his wording is practically similar:

Ein strengwissenschaftlicher Aufbau unserer ganzen Mythologie ist so lange micht möglich, als nicht von jeder einzelnen Tradition alle Varianten Gau bei Gau, Ort bei Ort gesammelt in ihrer ethnographischen Verbreitung bis auf die letzte Grenze und in ihrer historischen Entwickelung bis auf ihre erste Erwähnung rückwärts verfolgt sind. So erst wird es möglich, die ursprüngliche Form, die ursprüngliche Heimat und den ursprünglichen Gedankeninhalt derselben aufzufinden. (Mannhardt 1865a: 13)

Mannhardt's survey was the first of its kind and Mannhardt is generally praised for his systematic collection of material. Nobody would disagree with Mannhardt when he says that collections where "Ein jeder Sammler hat im wesentlichen nur solche Überlieferungen dem Volksmunde abgelauscht, nach denen er aus besondere Neigung fragte" (Mannhardt 1865a: 13), are open to fortuitous interpretations. At the same time few, today, would concur with Mannhardt in his enthusiasm for "die ursprüngliche Form" and certainly not regard it as historical. 


\section{Mannhardt as Historian and Phenomenologist}

Compared to many contemporary mythologists, Mannhardt's approach is much more historical. Again and again Mannhardt says: "Jede Überlieferung ist zuerst aus sich selbst und aus ihrem nächsten Umkreise zu erklären" (Mannhardt 1874-76/2: xxix). The strength of Mannhardt's work is this determined effort to view every custom and tradition in its historical context. The emphasis in the quotation, however, could just as well lie on zuerst, because Mannhardt's intention is clearly first to explain a tradition in its own terms and from its own background, but only to free the real pristine tradition from later outgrowths. The task as Mannhardt saw it was "... den Kern, die anfängliche echte Volksvorstellung aus den umhüllenden Schalen zu lösen" (Mannhardt 1874-76/2: xxxiii).

The analysis had to begin by removing late additions like Christian reinterpretations or rationalizations; then, a thorough comparative investigation had to be undertaken to classify the different phenomena and to find the core, the essential idea. As Mannhardt saw it, comparative analysis was a historical undertaking. The clearer and purer the essential idea - "die Grundanschauung" - the closer Mannhardt felt to be the pristine religion.

Today we would regard Mannhardt's pristine religion as fiction. We would see Mannhardt's comparative efforts as a phenomenological analysis and regard "die Vegetationsdämon" as "a phenomenon" or a theoretical construct. But whatever the construction is called, it has to have a solid empirical basis and to prove useful for the analysis. Mannhardt's basis is the investigation of agricultural folk traditions. Why did Mannhardt choose to investigate "den mytischen Gebräuchen beim Ackerbau" (Mannhardt 1874-76/2: xxxiv)? And why was that a good idea?

\section{Mannhardt's Theme: Mytischen Gebräuchen beim Ackerbau}

Mannhardt's first choice of subject for his survey was "mythischen und magischen Lieder" he gave it up, however, for practical and methodological reasons. In a speech given in 1865 in Halberstadt to der ersten Generalversammlung des Gesammt-Vereinnes der deutschen Geschichtsund Alterthums-Vereine", Mannhardt says:

Lieder sind, insofern sie nicht an bestimmt überall vorkommende Feste oder Thätigkeiten geknüpft sind, leichter vergänglich als andere Volksüberlieferungen 
und daher viel schwerer aufzufinden, ihr Vorhandensein oder Abgang in einem bestimmten Landstriche viel schwieriger festzustellen. Dagegen fallen die Ackerbaugebräuche viel deutlicher ins Auge, und während jene nur erlauscht, wem das Volk sein Herz und Vertrauen eröffnet, vermag über diese schon ungeübterer Beobachter, der nur Zuschauer war, manches zu berichten. (Mannhardt 1865b: 83; Beitl 1933: 76)

Mannhardt chose farming customs because they were rather easy to observe, but he had other reasons as well. Farming customs as a whole were too wide a field; to manage the material he limited his survey to harvest customs; they could be followed back in time, and:

Noch von einer andern Seite her bieten die Erntegebräuche die Gewähr eines günstigen Erfolges für die Aufgabe, der deutschen und vergleichenden Mythologie und Sittenkunde positive Grundlagen zu schaffen. Bisher ging die vergleichende Mythologie von den mythischen Vorstellungen aus und suchte... durch Muthmassung die unbekannte Grösse ihres Inhalts, den zu Grunde liegenden Anlass der Anschauung zu finden. Hier schliesst sich die Untersuchung umgekehrt an die unzweifelhaft feststehende Sache, an die bekannte Grösse eines im menschlichen Leben notwendigen Aktes an, um welchen sich in mythischdenkenden Zeitaltern mythische Vorstellungen lagern mussten ... (Mannhardt 1865b: 84; Beitl 1933: 77)

Mannhardt made no clear-cut distinction between myths and rites and his reasons for focusing on customs and rituals were primarily practical. Harvest customs are widespread, it is easy to ascertain their existence, and no special training is required of the informants. Harvest customs are stable and therefore suitable for analysis stretching over long periods of time. But the crucial point is the last, that: "Hier schliesst sich die Untersuchung ... an die unzweifelhaft feststehende Sache, an die bekannte Grösse eines im menschlichen Leben notwendigen Aktes an". Myths can be treated detached from the human beings telling them and using them; and there is a risk that the analysis will end in intellectual or poetic abstractions, as was the case for the nature mythologists in the last century. Rituals are more clearly and inextricably bound up with social life. The strength of Mannhardt's analysis of Wald- und Feldkulte is precisely that it is embedded in the reality of peasant life. This reality drew Mannhardt's attention away from the mythical-poetical to the practical-technical. 


\section{Religion and Society - von Sydow's Critique}

Not everybody would agree that Mannhardt's strength is his close touch with reality. In point of fact the Swedish folklorist C. W. von Sydow has criticized Mannhardt for exactly the opposite, for fancying elaborate religious beliefs behind customs with no such content. Only a bookish person without a real feel for the true character of the folk festivals could fail to see that there was no conception of a vegetation-daemon behind these peasant traditions, only youthful fun and merriment:

If you are present, and see how it happens, you cannot avoid noticing that it is only a joke. The closeted scholar who reads information about such things in the form of dry excerpts, takes everything seriously; and if he thinks it seems too queer for people to believe, he persuades himself that now it is only a survival, but that formerly people believed firmly and sincerely in the whole thing! (Sydow 1948: 101)

von Sydow's critique is not unjustified, but even more than Mannhardt von Sydow seems to be under the misapprehension that fun, joking and merriment can have nothing to do with belief and religion. It is certainly appropriate to emphasize the fun and merriment in the harvest festivals and that they are on the border of official religion, but Mannhardt is actually well aware of these facts as can be seen for instance in his treatment of customs like birching and flogging with different kinds of greenery. C. W. von Sydow's rather harsh critique is in a sense directed towards the subsequent, more incautious, use of Mannhardt's work, first and foremost by James Frazer. Had it not been for Frazer, Mannhardt might have been completely forgotten; in the Preface to the first edition (1890) of The Golden Bough Frazer generously acknowledged Mannhardt's importance for his own work: "... the works of the late W. Mannhardt, without which, indeed, my book could scarcely have been written" (Frazer 1911: xii). Frazer is, however, more heavy-handed than the cautious Mannhardt; he is more mechanical and one-sided in his ritualism, in his use of fertility-interpretations, and in his use of survival-arguments. Furthermore, Mannhardt's most original contribution is not his publications, but the questionnaire, on which he based his survey of harvest customs. 


\section{Religion and Society - Mannhardt's Questionnaire}

In regard to the harvest-customs Mannhardt's special interest is clearly the different personifications of vegetation. The question regarding the personifications of "the last sheaf" is the most detailed and elaborate in the whole questionnaire and the importance clearly indicated. It starts: "Ein besonderes Augenmerk bittet man auf die folgenden Fragen zu richten!" Here as elsewhere Mannhardt starts with an open and broad question: "Sind insonderheit beim Schneiden der letzten Halme auf einem Ackerfeld, beim Binden der letzten Garbe und beim Ausdreschen des letzten Gebundes noch besondere altertümliche Sitten vorhanden?" He exemplifies the customs related to the last sheaf by giving typical names for it, by telling how it is sometimes formed like a doll, sometimes shaped like a human being and he finishes with some very specific questions: "Wie nennt man die letzte Garbe? Was ruft man demjenigen, der sie bindet (resp. die letzten Halme schneidet) zu? Wird die Puppe nach jeder Frucht (Roggen, Gerste, Weizen, Erbsen, Hafer, Kartoffeln u. s. w.) gemacht? Wird in die letzte Garbe ein Stein eingebunden? Eine kleine Zeichnung der Kornpuppe wäre erwünscht. ..." (Mannhardt 1868: Anhang). Mannhardt takes great care to ensure that his questions are broad enough to catch various kinds of information, and at the same time so precise and specific that he gets the information he wants.

Even more significant is the fact that Mannhardt is always aware of the importance of the broader context of the different customs. He takes care to ask about similarities to other farming customs, connections to church activities and social relationships. Most important are, however, the questions that have to do with the most obvious context in which the harvest customs are imbedded, the work. Question no, 2 has to do with how the work is done: "... Wird das Getreide von den Bauern mit der Sichel oder mit der Sense geschnitten?..." and no. 3 who does the work: "Wird das Schneiden der Frucht und das Binden der Garben von denselben Personen besorgt, oder durch verschiedene? (Männer und Frauen? Fremde Arbeiter?)" The German folklorist Ingeborg WeberKellermann, who has gone through all the answers to the questionnaire, has found that these questions were the ones that gave the most elaborate and detailed responses (Weber-Kellermann 1965: 314).

The questionnaire shows that Mannhardt was not so blind to the realities of peasant life as von Sydow would have it. In the questionnaire he asked systematically for the social and religious context of the harvest customs. It is an indication of the care with which Mannhardt conceived 
his questions that they actually gave relatively ample responses. Furthermore it is worth mentioning that the answers to the questions worked out by this "bookish" and "closeted scholar" could a 100 years later be used by Weber-Kellermann as source material for a book on the social conditions and the work-relations of the 19th century German peasantry.

\section{Mannhardt as a Student of Rituals}

I have dealt with Mannhardt as he saw himself, that is as a mythologist and a historian; and I have dealt with him as he can be seen by us, as a phenomenologist and a student of rituals and social relations. Mannhardt's scholarly work can not be contained within the framework either of his time or ours. But precisely because he is an outsider, his work gives us an opportunity to contemplate the advantages and drawbacks to the different approaches, especially as they relate to the study of rituals.

In this connections it is significant that Mannhardt, so to say, became a student of rituals in spite of himself. His source material was "der lebendige Volksglaube" and his goal was: "Ihn in seiner echten Form zu ermitteln und in seinen Entwickelungsphasen bis auf die ursprüngliche, die Grundidee am reinsten ausdrückende Fassung zu verfolgen, ..." (Mannhardt 1874-76/2: xxviii). He started in mythology but found that the mythological theories of his time could not stand up to critical scrutiny. The foundation was not secure; sources were used in an unsystematic and haphazard way. To remedy the deficiency, Mannhardt engaged in a superhuman effort to collect reliable source material, and in this effort he came to realize that customs and rituals constituted the most trustworthy material. In spite of his avowed intention to devote himself to the study of prehistory and mythology, he came to focus on rituals and contemporary customs in his work; and so, indirectly, he showed how important the study of ritual is for historical studies of religion.

The ritualistic approach chosen by Mannhardt is also noteworthy for being contextual. In the questionnaire, Mannhardt shows a keen sense of the importance of seeing the harvest customs in the context of work, of social relationships, of church-life and Christianity, of eroticism, of fun and merriment; in short, in the context of peasant life as a whole. The strength of Mannhardt's analysis is that he sticks to the insights won through the questionnaires. In his interpretation he emphasizes that the 
farming customs have to do with fertility, prosperity and good health for human beings, animals, and crops.

Still, when it comes to the more theoretical reflections, Mannhardt lets go of the context. In his enthusiasm to uncover "die ursprüngliche... Grundidee am reinsten" he does away with the context and tends to overmythicize the bonds and transactions between plant life and human life. His contribution, however, is in a way exemplary in this sense, too; when religion is regarded as a world apart, as something outside or besides the reality of everyday life, the interpretations have a tendency to lose sight of their empirical basis, i.e. the human carriers of the religious concepts.

There are complicated relations between rituals, myths and general concepts, between the interests of various groups and how they use the religious repertoires. There are complicated relations between a scholar's ideas and the ideas of his time, between what he intends to do and what he actually does and achieves. It is not my intention to give the impression that Mannhardt did the right thing but for the wrong reasons. The dynamic behind Mannhardt's achievement is outside "right" and "wrong". Undismayed by ill-health, physical disability and an almost total lack of recognition, Mannhardt continued his studies for the best of all reasons: they were his consuming passion. In a letter to his always critical friend, the philologist Karl Müllenhoff, Mannhardt writes:

Auch das begreife ich sehr wohl, dass Ihnen vieles, was ich gesagt, sanguinisch und idealistisch vorkommen muss, so wie, dass ich in Anwendung der Gesetze, die ich als die richtigen erkannt, noch ungeübt und nicht scharf genug bin. Ich habe eben meiner ganzen Geistesanlage nach eine nüchterne Betrachtung der Dinge mühsam zu erkämpfen, aber ich ringe stätig darnach. Auf der andern Seite bildet gerade diese Schattenseite meines Wesens seine Stärke und mein Idealismus hilft mir im Leben Schweres mit Leichtigkeit tragen und in meiner Arbeit ausdauern, er gibt mir Wärme und Ueberredungskraft und so hoffe ich soll gerade dadurch mir gelingen meine Agitation - wie Sie selber es nennen - zu einem gedeihlichen Ziele hinauszuführen. (Mannhardt 1884: xx)

Note:

I wish to thank Professor Svein Bjerke for his very constructive and helpful comments on my presentation at the conference. 


\section{References Cited}

\section{Beitl, Richard}

1933 Wilhelm Mannhardt und der Atlas der deutschen Volkskunde. Zeitschrift für Volkskunde N. F. 4: 70-84.

\section{Frazer, James}

1911 The Magic Art and the Evolution of Kings. 2. vols. London: Macmillan \& Co. (The Golden Bough, 1,1)

Mannhardt, Wilhelm

1858 Germanische Mythen. Berlin: F. Schneider.

1860 Götterwelt der deutschen und nordischen Völker. Berlin: H. Schindler.

1865a Roggenwolf und Roggenhund. Danzig: Ziemssen. (Beitrag zur germanischen Sittenkunde)

1865b Vortrag gehalten in der ersten Generalversammlung des Gesammt-Vereins zu Halberstadt. Correspondenzblatt des Gesammtvereinnes der deutschen Geschichts- \& Alterthumsvereine 13: 81-88, 91-93.

1868 Die Korndämonen; Anhang: Der Fragebogen. Berlin: F. Dümmler. (Beitrag zur germanischen Sittenkunde)

1874-76 Wald- und Feldkulte. 2. vols. 1: Der Baumkultus der Germanen und ihrer Nachbarstämme: mythologische Untersuchungen. 2: Antike Wald- und Feldkulte aus nordeuropäischer Überlieferung erläutert. Berlin: Gebr. Bornträger.

1884 Mythologische Forschungen aus dem Nachlasse von Wilhelm Mannhardt. Hrsg. von Hermann Patzig. Strassburg: Trübner. (Quellen und Forschungen zur Sprach- und Culturgeschichte der germanischen Völker, 51)

Sydow, C. W. von

1948 Selected Papers on Folklore. Copenhagen: Munksgaard.

Weber-Kellermann, Ingeborg

1965 Erntebrauch in der ländlichen Arbeitswelt des 19. Jahrhunderts, auf Grund der Mannhardtbefragung in Deutschland von 1865. Marburg: N. G. Elwert Verlag. (Veröffentlichungen des Instituts für mitteleuropäische Volksforschung an der Philipps-Universität Marburg-Lahn, A. R. 2) 